\title{
NeMZETKÖZI FELSŐOKTATÁSI SZAKPOLITIKÁK TALÁLKOZÁSA EGY INTERDISZCIPLINÁRIS KONTEXTUSBAN
}

\author{
MAYER ANNAMÁRIA \\ Budapesti Corvinus Egyetem, Szociológia Doktori Iskola
}

\begin{abstract}
Jeroen Huisman, Harry d. Boer, David D. Dill \& Manuel Souto Otero: The Palgrave International Handbook of Higher Education Policy and Governance. Houndmills, Basingstoke, Hampshire, New York (NY), 2015. Palgrave Macmillan. xxxi + 604 p. ISBN: 978-1-137-45617-5 (eBook)
\end{abstract}

A könyv szerkezete első ránézésre egyszerűvé teszi az áttekintést: 30 , folytatólagosan számozott fejezet, két külön álló részre tagolva. Az első rész (1-12. fejezet) különböző elméleti megközelítéseket ismertet, a második rész témák szerint hat blokkra oszlik (13-30. fejezet). A blokkok a következők: A: Felsőoktatás, társadalom és gazdaság; B: A felsőoktatás megszervezése; C: A felsőoktatás kormányzása, irányítása; D: A felsőoktatás finanszírozása; E: Elszámoltathatóság és minőség; F: Egyenlőtlenségek a felsőoktatásban. A tanulmányok szerzői között szerepelnek híres, tapasztalattal rendelkező kutatók, oktatók, akárcsak frissen végzett $\mathrm{PhD}$ hallgatók írásai is.

Földrajzi lefedettség szempontjából a szerzők rendkívül széles skálán mutatják be a felsőoktatás kormányzását, irányítását érintő folyamatokat, koncepciókat. Egyes fejezetek főként Európára vagy egyes országokra helyezik a hangsúlyt, míg mások globális perspektívából közelítik meg a témát. Sok helyen visszaköszön Burton Clark munkássága, aki az amerikai felsőoktatási kutatások alapjainak lefektetésében meghatározó szerepet játszott.

A könyv első fejezeteiben (1-től 5-ig) a szerzők egy tágabb elméleti perspektívában többek között kitérnek arra, hogy müködés szempontjából a felsőoktatási intézmények és a kormányzati intézmények hogyan térnek el egymástól (1. fejezet), ismertetik az állam és a felsőoktatás kapcsolatát jellemző változásokat, az irányítás (steering), a kormányzat (government) és a kormányzás (governance) elméleti megközelítésmódjainak különbözőségeit, amelyben új szereplőként az üzleti szféra is megjelenik (2. fejezet), illetve kitérnek a különböző kormányzati modellek és politikai eszközök (3. fejezet), valamint az új közszolgálati menedzsment irányzat jellemzőire (4. fejezet), az 5. fejezetben a szerzők a felsőoktatás többszintű kor- 
mányzásának elméleti hátterét ismertetik szervezeti szinten.

A 6. fejezet fóként Európát helyezi a középpontba, elemezve a felsőoktatási kormányzási irányelvek alkotmányos és intézményes jogi hátterét. A 7. fejezetben többek között egy gyakori szakirodalmi problémára hívják fel a szerzők a figyelmet, ami nem más, mint az, hogy az intézmények (institutions) és a szervezetek (organizations) fogalmát számos kutató helytelenül használja, mintegy egymás szinonimájaként.

Ezután olyan elméleteket ismerhetnek meg az olvasók, mint az üzleti és a menedzsment tudományterületeken belül viszonylag ismert, azonban a kvantitatív kutatások területén kevésbé alkalmazott agency elméletet (8. fejezet), illetve egy globális perspektívából vizsgálva a strukturális változásokra reflektáló rendszerelméletet (system theory) (9. fejezet).

Míg egyes fejezetekben a szerzők saját tapasztalataikra hagyatkozva jelölik ki, hogy melyek a többnyire kutatott, illetve kevésbé kutatott tématerületek, addig a 10. fejezet egy szisztematikusabb szakirodalmi áttekintést nyújt a témában, amelyhez a szerzök különböző szempontok alapján a 2000 és 2010 között megjelenő, elsősorban felsőoktatásra fókuszáló folyóiratokat elemeztek, ráadásul a tanulmány megjelenése elött friss adatokkal is összehasonlították az eredményeiket.

A z előző fejezethez szorosan kapcsolódóan a 11. fejezet egy tömör összefoglalót tartalmaz az intézményekre irányuló kutatások döntéseket támogató funkciójáról, kitérve a felsőoktatásra ható piaci viszonyokra, ugyanakkor jellemezve az intézményre irányuló kutatás (institutional research) és az oktatásra irányuló kutatás (educational research) közötti különbségeket.

A hálózati elemzés operacionalizálása a felsőoktatási kutatások számára c. fejezet az előző fejezetekhez képest empirikusabb megközelítésű, valós példán keresztül nyújt betekintést a hálózatelemzés alapjaiba. A szerzők azt vizsgálják, hogy a kiválasztott 18 egyetem hogyan kapcsolódik egymáshoz egy nemzetközi együttműködési konzorcium keretén belül, elemezve, hogy mely egyetemek követik egymást a Twitter közösségi média platformon keresztül.

Ahogyan az előbbiekben már említettem, a könyv második részében a tanulmányok különböző blokkokra vannak bontva. Az első blokkban (A. - Felsőoktatás, Társadalom és Gazdaság) a szerzők többek között olyan kérdésekre keresik a választ, mint hogy: Milyen külső nyomások hatnak a felsőoktatásra regionális, illetve lokális szinten? A kormányzati szervek hogyan reagálnak ezekre a változásokra? (13. fejezet.) Hogyan jellemezhetök az országokon átívelő és a nemzeti felsőoktatási intézményeken belüli kormányzati mechanizmusok, stratégiák - különös hangsúlyt fektetve a kutatást és az innovációt érintő kormányzási stratégiákra? (14. fejezet), illetve ehhez szorosan kapcsolódóan, intézményi szinten vizsgálva: Hogyan befolyásolja az intézményes kormányzás és a menedzsment gyakorlata a kutatási kiválóságra ösztönző szakpolitikákat? (15. fejezet.)

A felsőoktatás nemzetközivé válása c. fejezetben az olvasók átfogó képet kaphatnak arról, hogy a kormányok hogyan reagálnak a felsőoktatási intézményeket érintő globális és lokális nyomásokra, míg az ezt követő fejezetben a gazdasági szektor és a felsőoktatási intézmények kapcsolatát vizsgálva a szerzők az egyes fogalmak meghatározásán túl kitérnek többek között az OECD és az Egyesült Államokban végzett kutatási eredmények bemutatására. Ugyanakkor rámutatnak arra, hogy nem a foglalkoztathatóság, hanem az alulfoglalkoztatottság szempontjából kellene megközelíteni a témát. 
A felsőoktatás szervezése c. blokkon belül, a 18. fejezetben a szerzők egy rendszerszintü perspektíva alapján írják le azt a Nyugat-Európára (és egyre inkább nemcsak Nyugat-Európára) jellemző trendet, amelyben a felsőoktatást újra reformálják a neoliberális és a piaci, gazdasági viszonyok mentén. Míg itt a fejezet középpontjában az angliai felsőoktatási rendszer áll, addig a következő fejezet egy tágabb nézőpontból közelíti a témát - többek között párhuzamot vonva az amerikai és az európai oktatási rendszerek között, megvizsgálva az IKT-eszközök lehetséges hatásait a felsőoktatásra nézve. Kétfajta IKT-alapú fejlesztést különböztetnek meg: azok a fejlesztések, amelyek föként azt befolyásolják, hogy hol és mikor tanulunk, illetve azok, amelyek azt befolyásolják, hogy hogyan tanulunk. Utóbbira példaként kiemelném, hogy míg Amerikában elterjedőben vannak az online kurzusok, amelyekért az egyetemeken a hallgatók krediteket kaphatnak, addig Európán belül ezek napjainkban még mindig ritkának számítanak.

A Felsőoktatás kormányzása, irányitása c. blokkon belül, a 20. fejezetben a szerzők globális nézőpontból (Európa, Afrika, Ázsia, Latin-Amerika) közelítik meg a témát, megkülönböztetve az interregionális és intraregionális fogalmakat. Ehhez egy háromdimenziós rendszerszintü szisztematikus összehasonlító elméleti keretet alakítottak ki, amely a regionális, kvalitatív jellegü kutatások terén újszerü szemléletet nyújthat az olvasók számára. $\mathrm{A} z$ elméleti keretrendszer kialakítása mellett ugyanakkor kitérnek a gyakorlati alkalmazásra is, bemutatva azt a Bologna-rendszer kontextusában.

$\mathrm{A} z$ ezt követő fejezet egy szisztematikus szakirodalmi áttekintés, amelyben a szerzők különböző adatbázisokból szelektált (EBSCOhost, Academic Search Premier, Business Source Elite, ERIC és SocINDEX), 2004-ben és 2014-ben megjelent tanulmányokat vizsgáltak (53 tanulmányt), amelyekben a következő három kérdésre keresték a választ: Milyen indokból vezetik be a kormányok azokat a különböző szakpolitikákat, amelyeknek célja az intézményi irányítás szerkezeti átalakítása? Hogyan reagáltak a felsőoktatási intézmények ezekre a szakpolitikákra? Milyen következményei vannak a bevezetett szakpolitikai változásoknak egyetemi szinten?

A 22. fejezetben a szerzők, többek között a Transforming Universities in Europe (TRUE) címü kutatási projekt eredményeire támaszkodva, egy viszonylag kritikus, intézményszintű megközelítésben vizsgálták Európán belül és kívül külön az egyes országokra kitérve, a „boardism” jellemzőit a felsőoktatásban és annak a felsőoktatási kormányzásra való hatását. Pontosabban az akadémiai „önkormányzástól” a menedzseri kormányzásig vezető változásokat, folyamatokat írják le, mint a hatalmi viszonyok változásait, olyan kérdésekre utalva, minthogy „Létezik a felsőoktatásban a közös irányítás eszménye?”, amelyre, mintegy válaszként, a következő erős kritikát fogalmazták meg: „a közös irányítás fogalma annyira tág, hogy nem tükrözi, nem írja le megfelelőképpen a valódi hatalmi viszonyokat".

Szorosan kapcsolódva az előző gondolatmenethez, globális szinten megközelítve a témát és szintén viszonylag kritikus szemléletmóddal, a következő fejezetben az egyetemi rangsorok felvirágzására térnek ki a szerzők - fóként azok negatív hatásait kiemelve. A világ három legismertebb egyetemi rangsorához (Shanghai Academic Ranking of World Universities, Times Higher Education (THE) World University Rankings, QSWorld University Rankings) viszonyítva mutatják be a U-Multirank egyetemi rangsort, amely szerintük egy olyan alternatív, komplex, 
multidimenzionális egyetemi rangsor, amely igyekszik megfelelni a "fogyasztói”, azaz a hallgatók és egyetemi menedzserek, vezetői pozíciókban elhelyezkedők igényeinek. Véleményüket jól mutatja, hogy az U-Multiranket az egyetemi rangsorok 2.0-ás verziójának nevezik. Kritikaként megfogalmazható, hogy a kötet objektív szemléletmódját megtörik, amikor például a következő kinyilatkoztatást teszik: „A U-Multirank a megjelenése óta segített abban, hogy megváltoztassa az egyetemi rangsorok közötti »játszmát«. Az a benyomásom, hogy 2009 óta egy bizonyos része a globális egyetemi rendszerek fejlesztésének nem jött volna létre az U-Multirank egyetemi rangsor színtérre lépése nélkül." A szerzők ok-okozati viszonyt feltételező, szubjektív módon értelmezett „benyomása" a fejezetben nincs kellokképpen adatokkal alátámasztva.

A felsöoktatás finanszirozása c. blokk írásai leginkább olyan kérdésekre keresik a választ, mint hogy: $\mathrm{A} z$ államvezetés hogyan szervezte meg a kutatások közfinanszírozását és ez az elmúlt években hogyan változott? A blokkon belül az első fejezet főként Európát helyezi a kutatás középpontjába, bár kitér globális folyamatokra is (24. fejezet), a második fejezet föként az Egyesült Államok kontextusában vizsgálja az említett kérdéskört (25. fejezet).

$\mathrm{A} z$ Elszámoltathatóság és minöség nevü blokk komparatív perspektívában mutatja be, hogy a különböző térségekben, föként Európában (ezen belül Angliában) és Ázsiában (leginkább Kínában) - az 1970es, 1980-as évektől napjainkig (2015) hogyan változott a felsőoktatási intézmények autonómiája, elszámoltathatósága és az állammal való kapcsolata. Viszonylag bővebben tárgyalják a Big Data elemzések és az egyetemi autonómia kapcsolatát. A következő fejezet egy tágabb témakörben vizsgálja, merően kritikus szemléletmóddal, a minőségbiztosítás, illetve a minőség javításának, fejlesztésének témaköreit. A szerzők kitérnek a „minőség” definíciójára, illetve többek között arra is, hogy a minőségbiztosítás, illetve a minőség fejlesztése tekintetében milyen típusú adatforrások állnak a kutatók rendelkezésére, illetve milyen problémákkal kell szembesülniük az elemzés során (27, fejezet). A 28, fejezet azt fejtegeti, hogy a minőségbiztosítási és minőségfejlesztési rendszerekben a hallgatók milyen szerepet töltenek be. A szerzők amellett érvelnek, hogy egy erős, kollektív, egyetemi identitás kialakításának szükséges feltétele a hallgatók felelősség- és tudatteljes bevonása az egyetemi minőségbiztosítási és fejlesztési rendszerekbe.

A könyv utolsó két fejezete végül a felsőoktatáson belüli egyenlőtlenségekre helyezi a hangsúlyt. Míg a 29. fejezetben a szerzők olyan kérdéseket taglalnak, mint hogy: A különböző kormányzati szakpolitikák milyen társadalmi csoportokat helyeznek elötérbe, illetve melyek maradnak úgymond „láthatatlanok”? Hogyan jellemezhető a hallgatói mobilitás és az egyre inkább növekvő tandíjak kapcsolata egy olyan kontextusban, ahol a szakpolitikák a felsőoktatásban való részvételi arányok bővítésére törekednek? A fejezet föként Kínára, az Egyesült Államokra és Angliára fókuszálva mutatja be, mennyire eltérők a kormányzási stratégiák, ugyanakkor kitér arra is, hogy a kiválóságról szóló diskurzusok és a meritokrácia gyakran hogyan járul hozzá az egyenlőtlenségek újratermelödéséhez.

Az utolsó fejezet a nemi egyenlötlenségeket taglalja egy többszintü, ugyanakkor kritikus megközelítési perspektívából. Felhívja a figyelmet arra, hogy jóllehet, a nők aránya a felsőoktatásban egyre növekszik, hozzáférésük a senior munkaköri pozíciókhoz változatlanul csak korlátozott mértékü. Míg számos fejezet a könyvben inkább elméleti megközelítésű (8. és 12.), addig ebben a fejezetben a szerzők nagyon 
széles skálán, különböző szinteken (egyéni, szervezeti, rendszer, illetve szélesebb kulturális intézményi szinten) ismertetik a nemi egyenlőtlenség témakörét.

Összességében a számos elméleti keret és a különböző kutatási eredmények ismertetése mellett a tanulmányok szakirodalomhoz hozzáadott értékeként kiemelendő, hogy a könyv első részében - illetve egyes tanulmányok esetében a második részben is - a szerzők viszonylag bővebben taglalják, hogy melyek azok a kutatási irányok, kérdések, amelyeket érdemes lenne a közeljövőben kutatni. Például a 17. fejezetben a szerzők felhívják a figyelmet arra, hogy a nemzetköziesítés hatásait a szakirodalomban föként az angol anyanyelvü országokban kutatták eddig, és főként a nyugati egyetemek perspektívájából nézve, míg a nem angol anyanyelvű országokban ilyen jellegü kutatásokra ritkábban került sor. Egy másik példa: A felsőoktatási diplomák számának növekedése hogyan járul hozzá a foglalkoztatottság kérdéséhez? A felsőoktatás expanziója fog-e alulfoglalkoztatottsághoz vezetni? (11. fejezet.)

A könyvben szereplő tanulmányok többnyire szorosan kapcsolódnak egymáshoz, ezt számos esetben maguk a szerzők is megjelölik. Például a 14. fejezetben reflektálnak az 5., illetve a 15. fejezetben tárgyalt témakörökre.
Kritikaként megjegyezném, hogy a 16. fejezetben hiányoltam a "készségek”, „kompetenciák”, „képességek” kifejezések meghatározását. A fogalmak egymás szinonimájaként való használata megtévesztő lehet az olvasók számára, ez sajnos a szakirodalomban is gyakori. A könyvben elvétve felbukkannak olyan fogalmak is, amelyek a nemzetközi olvasóközönség számára nem feltétlenül ismertek: "A-szintű osztályozás" (A-level grades), "AAB+" osztályozás (grades of $\mathrm{AAB}+$ ). Habár a könyv egyik fontos értéke éppen abban rejlik, hogy rendkívül sokszínü tudományterületeket ötvöz, hiányosságaként megemlítendő, hogy a nemzetközi tendenciák mellett viszonylag kevéssé érinti az egyes tudományterületeken belüli kontextusokat, mint például a felsőoktatásban végzettek tudományterületeken belüli elhelyezkedési lehetőségeit.

Összességében elmondható, hogy a könyv rendkívül érdekfeszítő kérdéseket taglal, illetve számos megválaszolatlan kérdésre hívja fel a figyelmet, így mindenképpen ajánlható úgy a politikatudományok, mint a nemzetközi kapcsolatok, menedzsment, közgazdaságtan, illetve a jogtudományok iránt érdeklődők számára, nem utolsósorban pedig a felsőoktatási intézmények vezetői pozícióiban dolgozók számára is.

A cikk a Creative Commons Attribution 4.0 International License (https://creativecommons.org/licenses/ by-nc/4.0/) feltételei szerint publikált Open Access közlemény, melynek szellemében a cikk bármilyen médiumban szabadon felhasználható, megosztható és újraközölhető, feltéve, hogy az eredeti szerző és a közlés helye, illetve a CC License linkje és az esetlegesen végrehajtott módosítások feltüntetésre kerülnek. 